\title{
p53 protein overexpression in bone marrow biopsies from chronic lymphocytic leukaemia is associated with TP53 deletion and resistance to fludarabine
}

\author{
Paloma Martin • Ayoma D. Attygalle • John Swansbury • Toon Min • Alison Morilla • \\ Sarah L. Hockley • Andrew Wotherspoon • Gareth J. Morgan • Daniel Catovsky • \\ Claire E. Dearden • Estella Matutes
}

Received: 30 July 2010 /Accepted: 14 September 2010 /Published online: 5 October 2010

(C) Springer-Verlag 2010

\begin{abstract}
Abnormalities of the TP53 gene in chronic lymphocytic leukaemia (CLL) are associated with large cell transformation, short survival and resistance to purine analogue therapy. Deletion of one allele and somatic mutation of the remaining allele have been described as the main mechanism of TP53 inactivation in CLL, but its relationship with $\mathrm{p} 53$ protein expression remains unclear. We studied 103 CLL patients using fluorescence in situ hybridisation (FISH) to detect allelic loss at chromosome $17 \mathrm{p}$ and immunohistochemistry (IHC) to test for $\mathrm{p} 53$ protein overexpression. TP53 deletion ( $\geq 10 \%$ of cells) was found in 21 cases $(20.4 \%)$ and no deletion in 82 (79.6\%). By IHC, 16 cases (15.5\%) showed p53 protein expression and $87(84.5 \%)$ were negative. There was a good correlation between FISH and IHC in 86 cases $(83.5 \% ; p<0.001)$ and these comprised ten cases positive for both assays and 76 negative cases. The remaining 17 cases had discrepant results: 11 cases showed TP53
\end{abstract}

\section{P. Martin}

Department of Molecular Pathology,

Hospital Puerta de Hierro-Majadahonda,

Madrid, Spain

A. D. Attygalle $\cdot$ A. Wotherspoon

Department of Histopathology, Royal Marsden NHS Foundation

Trust, Institute of Cancer Research,

London, UK

J. Swansbury $\cdot$ T. Min $\cdot$ A. Morilla $\cdot$ S. L. Hockley $\cdot$

G. J. Morgan • D. Catovsky • C. E. Dearden • E. Matutes $(\bowtie)$

Section of Haemato-Oncology,

Royal Marsden Hospital \& Institute of Cancer Research,

Brookes Lawley Building, 15 Cotswold Road,

Sutton, Surrey SM2 5NG, UK

e-mail: estella.matutes@icr.ac.uk deletion and were p53 negative, and six cases had strong expression of protein and no TP53 deletion (FISH). Seventy-two patients $(70 \%)$ received fludarabine. The majority $(86 \%)$ of patients without abnormalities of TP53 responded to fludarabine and only eight cases were resistant. Within the rest, all patients positive with both methods were refractory, $60 \%$ of cases with overexpression without deletion and $40 \%$ of cases with deletion without protein overexpression were non-responders to fludarabine. Our findings indicate that IHC is a simple method and provides useful complementary information to FISH analysis for the evaluation of TP53 dysfunction. Both methods can be carried routinely to identify patients with a high chance to be resistant to fludarabine containing regimens $(p=0.0003)$.

Keywords Chronic lymphocytic leukaemia - TP53 · FISH · Immunohistochemistry

\section{Introduction}

B-cell chronic lymphocytic leukaemia (CLL) is characterised by a highly variable clinical course [1]. A number of biological markers such as mutational status of the immunoglobulin heavy chain variable gene (IGVH) [2, 3], CD38 and ZAP-70 expression [4-8] and cytogenetics, particularly TP53 and ATM abnormalities, have been shown to have prognostic impact to predict the disease course in patients with early stages and/or response to treatment in those with progressive disease [9-11].

The TP53 tumour suppressor gene, located on chromosome 17p13.1, encodes a nuclear 53-kDa phosphoprotein that plays a key role in response to cellular stress conditions by inducing 
the transcription of genes controlling cell cycle arrest and induction of apoptotic cell death. TP53 is one of the most commonly mutated genes in human cancers. In lymphoid malignancies, the frequency of TP53 abnormalities is low compared to solid tumours and varies with histological subtype and aggressiveness of the tumour [12]. In CLL, allelic loss of $17 \mathrm{p}$ and/or somatic mutation of the remaining TP53 allele have been described as the main mechanism of TP53 inactivation [13]. Mutant p53 cells lose the ability to bind p53-binding sites and/or changes the global conformation of the heterodimeric protein complex, leading to partial or complete loss of p53 protein functions [14]. Several studies have shown that wild-type p53 function is required for the cell to undergo apoptosis induced by genotoxic damage, and thus, tumours expressing mutant or deleted TP53 are likely to be chemoresistant to a wide range of anticancer drugs. Higher levels of p53 protein seem to result from a longer half-life of the mutated protein, arising from conformational changes that stabilise the protein. This abnormal long half-life of the protein allows its detection in the nucleus of the cells by immunohistochemical (IHC) techniques.

It is not clear whether expression of the non-functional aberrant $\mathrm{p} 53$ protein correlates with a mutated or deleted TP53 gene [15]. Although early studies suggested that this is the case, others have documented a lack of correlation and suggested that the TP53 pathway may also be disrupted in wild-type p53 tumours by other mechanisms like MDM2 amplification or mutations of the gene encoding ATM [16]. Although an association between protein overexpression and poor survival or non-response to therapy has been reported in CLL [5, 17-19], it still remains unclear which assay is the best to use routinely to detect TP53 dysfunction and predict drug resistance.

We have investigated the presence of TP53 deletion (fluorescence in situ hybridisation (FISH)) and p53 protein expression (IHC) to establish the extent of correlation between these two assays, and their impact in terms of resistance to treatment with fludarabine.

\section{Materials and methods}

Patients and specimens

Blood and bone marrow samples from 103 CLL patients (22 at diagnosis and 81 at follow up) investigated and followed at the Royal Marsden Hospital were analysed. This series did not include patients entered into the UK CLL-4 study. The diagnosis of CLL was based on morphology and immunophenotype according to the World Health Organisation classification [20]. All patients had immunophenotypic CLL scores [21] greater than three. FISH analysis was carried out on isolated peripheral blood mononuclear cells and expression of p53 was performed by IHC in bone marrow biopsies. Expression of CD38, ZAP-70 and IgVH mutations were performed as previously described [22]. Informed consent was obtained from all patients. Cases were drawn from the RMH CLL database and were selected those where FISH and IHC were investigated at the same time point.

Fluorescence in situ hybridisation

Peripheral blood lymphocytes were separated by density gradient centrifugation, treated with hypotonic solution $(\mathrm{KCl})$ and fixed with methanol-acetic acid. FISH analysis was performed using standard methods as previously described [19]. A TP53 locus specific probe (LSI p53 and CEP 17, Vysis, Downers Grove, IL, USA) in combination with a probe specific for chromosome 17 centromere (CEP17, Spectrum Green, Vysis) were used. Cells from ten healthy donors were used as control specimens. A total of 200 nuclei were scored per patient's sample by two individuals. A threshold of $\geq 10 \%$ deleted cells was considered to be clinically significant according to the results of the LRF CLL-4 trial [23].

\section{Immunohistochemistry}

Staining was performed on deparaffinized $3 \mu \mathrm{m}$ sections of routinely processed paraffined embedded tissue following heat-induced antigen retrieval using a monoclonal antibody to $\mathrm{p} 53$ protein, (clone NCL-p53-BP, Novocastra, Laboratories, Newcastle upon Tyne, UK) at a 1:50 dilution. Peroxidase enzyme staining with diaminobenzidine was used to visualise the $\mathrm{p} 53$ protein-positive cells. A case was considered positive when there was a strong nuclear staining in at least greater than $10 \%$ of cells [24]. Intensity of staining was considered to be more relevant than number of positive cells; those cases with few or weakly p53 positive cells with the staining confined to the proliferation centres were considered negative.

Statistical analysis

The correlation between TP53 deletion and IHC expression was assessed with the Fisher's exact test using SPSS software (version 15.0).

\section{Results}

Patients

Clinical features (Binet stages), treatment, genetic abnormalities other than TP53 deletion, mutational status of the 
IgVH and CD38/ZAP70 expression are summarised in Table 1.

There were 58 males and 45 females, with a median age at diagnosis of 54 years. At the time of this study close to a half of patients had stable stage A and the remaining had stages $\mathrm{B}$ and $\mathrm{C}$ or progressive stage $\mathrm{A}$. Nineteen cases $(18.5 \%)$ had not been previously treated, and 84 cases $(81.5 \%)$ were previously treated prior to the TP53 analysis. Among the latter, $72(85.7 \%)$ received fludarabine (36 cases as first line of treatment) either alone (19 cases) or in combination (17 cases). Alemtuzumab with or without methyl-prednisolone was given to $31(36.9 \%)$ patients and in six of them as first line. FISH analysis showed the presence of at least one chromosome abnormality in 68 $(66 \%)$ cases. Deletion of $13 q 14$ was found in over half of the patients and it was associated with either trisomy 12 or del11q $(A T M)$ in a third of them. Two thirds of the cases had unmutated IGVH and cells from greater than a third and two thirds of cases were ZAP-70+ and CD38+, respectively (Table 1 ).

Table 1 Patient characteristics

\begin{tabular}{|c|c|}
\hline No. of cases & 103 \\
\hline Age, years & $54.5(25-78)$ \\
\hline Male-female ratio & $1.3(58 \mathrm{M} / 45 \mathrm{~F})$ \\
\hline \multicolumn{2}{|l|}{ Stage } \\
\hline A stable & $48(46.6 \%)$ \\
\hline A progressive & $15(14.6 \%)$ \\
\hline B & $17(16.5 \%)$ \\
\hline $\mathrm{C}$ & $10(9.7 \%)$ \\
\hline Unknown & $13(12.6 \%)$ \\
\hline \multicolumn{2}{|c|}{ Interphase cytogenetics } \\
\hline $\operatorname{del}(11 q)$ & $19 / 99(19.2 \%)$ \\
\hline+12 & $20 / 99(20.2 \%)$ \\
\hline $\operatorname{del}(13 q)$ & $55 / 99(55.5 \%)$ \\
\hline \multicolumn{2}{|c|}{$\mathrm{IgVH}_{\text {mutation status }}{ }^{\mathrm{a}}$} \\
\hline IgH unmutated & $45 / 72(62.5 \%)$ \\
\hline IgH mutated & $27 / 72(37.5 \%)$ \\
\hline ZAP70+ & $35 / 93(37.6 \%)$ \\
\hline CD38+ & $70 / 97(72.2 \%)$ \\
\hline No treatment & $19 / 103(18.5 \%)$ \\
\hline Treatment & $84 / 103(81.5 \%)$ \\
\hline Fludarabine & $72 / 84(85.7 \%)$ \\
\hline \multirow[t]{3}{*}{ 1st line } & 36 cases \\
\hline & $19 \mathrm{FL}$ \\
\hline & 17 in combination $(12 \mathrm{FC}, 5 \mathrm{FCR})$ \\
\hline Alemtuzumab & $31 / 84(36.9 \%)$ \\
\hline 1 st line & 6 cases \\
\hline
\end{tabular}

${ }^{\text {a }}$ Cutoff of $98 \%$

$F L$ fludarabine alone, $F C$ fludarabine plus cyclophosphamide, $F C R$ fludarabine plus cyclophosphamide plus rituximab
Fluorescence in situ hybridization and IHC analysis of TP53

Out of 103 CLL cases, 21 (20.4\%) had $\geq 10 \%$ of cells with deletion of one TP53 allele and no deletion $(<5 \%)$ was found in 82 cases $(79.6 \%)$. Out of the 21 TP53 deleted cases, $13 \mathrm{had}>20 \%$ cells with the gene deletion. No single case showed biallelic deletion of TP53. By IHC, 16 cases $(15.5 \%)$ showed strong nuclear protein staining in the majority of cells and $87(84.5 \%)$ were p53 negative. Concordance between FISH and IHC was found in $83.5 \%$ cases: 76 cases $(73.8 \%)$ were negative for both assays (FISH and IHC) and ten cases $(9.7 \%)$ were positive for FISH and IHC (Table 2). Deletion of TP53 gene and p53 expression were strongly correlated $(p=0.00006)$. The remaining 17 cases $(16.5 \%)$ had discrepant results as follows: 11 cases showed TP53 deletion by FISH and were p53 negative (IHC), and six cases had strong expression of p53 (IHC) in $>10 \%$ of cells and no evidence of TP53 deletion (FISH). A total of 27 cases showed one or both abnormalities (Fig. 1).

Correlation between TP53 abnormalities and response to fludarabine-based regimens

Responses [25] to fludarabine containing regimens according to TP53 status in each group (concordant and discordant cases) are shown in detail together with other prognostic factors in Tables 3 and 4 and summarised in Table 5. The vast majority of patients without abnormalities of TP53 $(86 \%)$ responded to fludarabine whilst only a minority (eight cases; 14\%) without TP53 abnormalities by FISH and IHC were resistant (Table 5).

The presence of TP53 abnormalities by FISH and/or IHC was significantly $(p=0.0003)$ associated with resistance to fludarabine alone as well as fludarabine-containing regimens (fludarabine plus cyclophosphamide, fludarabine plus cyclophosphamide plus rituximab).

All patients positive with both methods that received fludarabine were refractory and all these non-responders were CD38 positive and half of them had somatic mutations in the IgVH; no case had ATM deletion and two cases had trisomy 12 (Table 4). In this concordant group, three patients received first line Alemtuzumab in combination with high-dose methyl-prednisolone, and one patient Alemtuzumab alone and all four achieved a complete response. Five of the fludarabine refractory patients subsequently received Alemtuzumab after more than three lines of treatment achieving a good response.

In the IHC-positive FISH-negative discordant group, five out of six patients received fludarabine (two alone and three in combination), three of them (60\%) being refractory. 
Table 2 Correlation between FISH status and IHC results

\begin{tabular}{lcccl}
\hline & IHC negative & IHC positive & Total & \\
\hline FISH negative & $76(73.8 \%)$ & $6(5.8 \%)$ & $82(79.6 \%)$ & \\
FISH positive & $11(10.7 \%)$ & $10(9.7 \%)$ & $21(20.4 \%)$ & $p=0.00006$ \\
& $87(84.5 \%)$ & $16(15.5 \%)$ & $103(100 \%)$ & \\
\hline
\end{tabular}

FISH positive: in $\geq 10 \%$ of cells TP53 loss
Only one of the non-responders was treated with Alemtuzumab achieving a complete remission.

In the other FISH-positive IHC-negative discordant group, six out of 11 patients received fludarabine (four alone and two in combination) and a third of them were refractory. Two cases received Alemtuzumab as first line treatment achieving a complete remission.
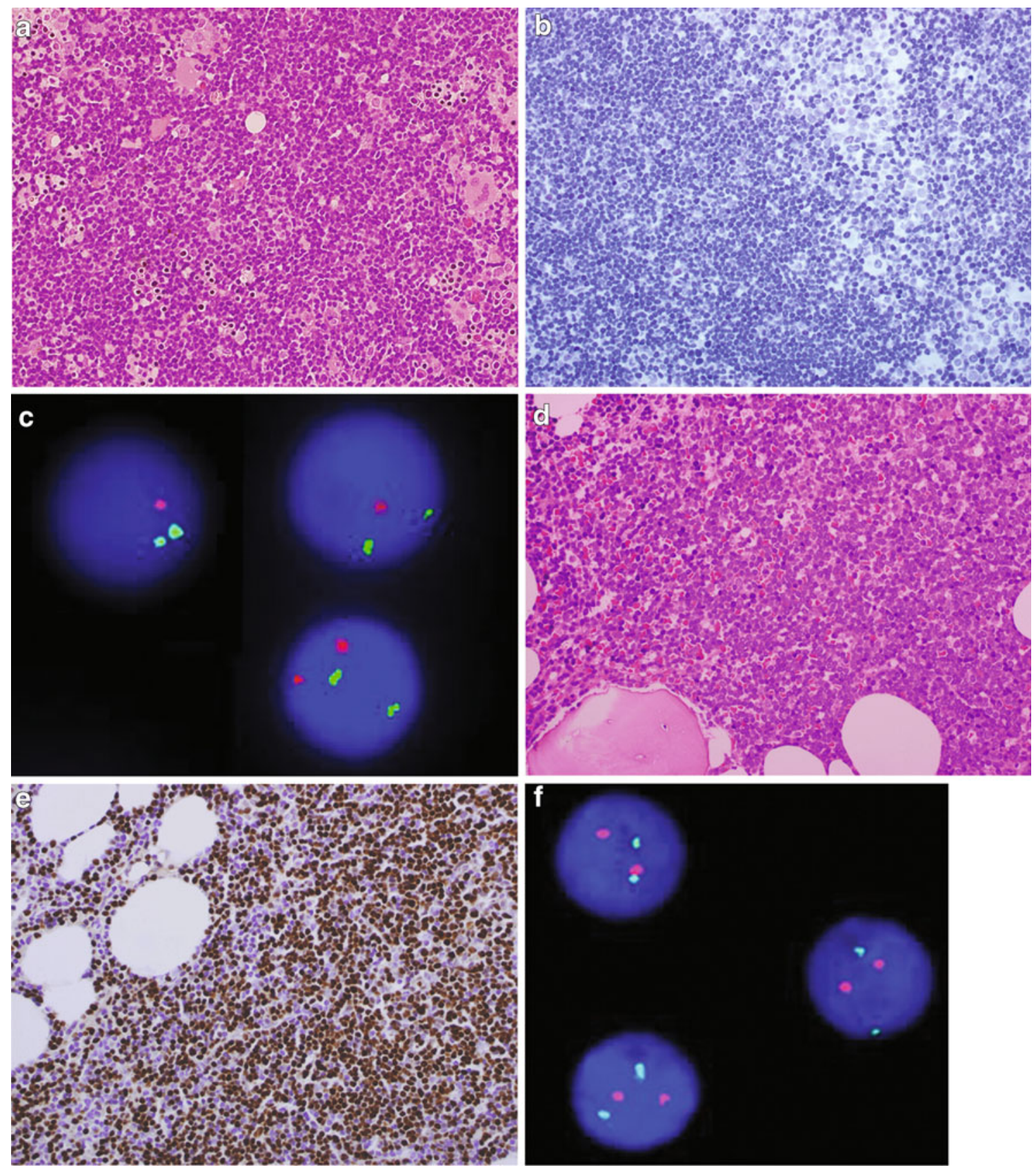

Fig. 1 Bone marrow biopsy of B-CLL with interstitial and nodular infiltration by small lymphoid cells H\&E magnification $\times 40$ (a). Neoplastic cells are negative for p53 (b) with monoallelic TP53 deletion by FISH (c). d Bone marrow biopsy of B-CLL (H\&E

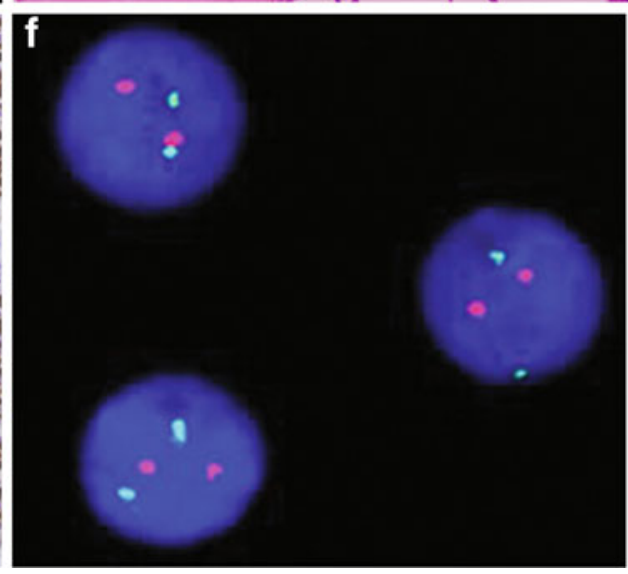

magnification $\times 40$ ) with a nodular and dense infiltrate of lymphoid cells with marked overexpression of p53 (e). This case does not have deletion of TP53 by FISH (f) 
Table 3 Correlation between TP53 abnormalities and response to therapy
TP53 deletion + when present in $\geq 10 \%$ of cells

$F L$ fludarabine alone, $F C$ fludarabine plus cyclophosphamide, FCR fludarabine plus cyclophosphamide plus rituximab

\begin{tabular}{|c|c|c|c|c|}
\hline Sample & IHC overexpression & FISH deletion & Treatment & Response to fludarabine \\
\hline 1 & + & + & 1st FL, 2nd FC & No response \\
\hline 2 & + & + & Campred & Complete Remission \\
\hline 3 & + & + & FL & No response \\
\hline 4 & + & + & Campred & Complete remission \\
\hline 5 & + & + & No treatment & \\
\hline 6 & + & + & Campred & Complete remission \\
\hline 7 & + & + & Campath & Complete remission \\
\hline 8 & + & + & 1st FL, 2nd FC & No response \\
\hline 9 & + & + & FL & No response \\
\hline 10 & + & + & $\mathrm{FC}$ & No response \\
\hline 11 & - & + & Campred & Complete remission \\
\hline 12 & - & + & FL & No response \\
\hline 13 & - & + & No treatment & \\
\hline 14 & - & + & Cyclophosphamide & Autoimmune disease \\
\hline 15 & - & + & Chlorambucil & Progression \\
\hline 16 & - & + & Campred & Complete remission \\
\hline 17 & - & + & FL & Good response \\
\hline 18 & - & + & FL & Good response \\
\hline 19 & - & + & 1st FL, 2nd FC & No response \\
\hline 20 & - & + & 1st FL, 2nd FC & Good response \\
\hline 21 & - & + & 1st FL, 2nd FCR & Good response \\
\hline 22 & + & - & 1st FL, 2nd FC & No response \\
\hline 23 & + & - & 1st FL, 2nd FCR & No response \\
\hline 24 & + & - & Chlorambucil & Autoimmune disease \\
\hline 25 & + & - & FL & Good response \\
\hline 26 & + & - & 1st FL, 2nd FC & Good response \\
\hline 27 & + & - & 1st FL, 2nd FCR & No response \\
\hline
\end{tabular}

\section{Discussion}

The prognostic impact of $17 \mathrm{p}$ (TP53) deletion in CLL patients has been documented in a number of single centre studies and randomised clinical trials [26-30]. However, the role of $\mathrm{p} 53$ protein expression and its correlation with deletion and mutations of the TP53 is uncertain and not well established. Some reports indicate that p53 overexpression is more sensitive than mutational analysis of the gene for predicting the risk of progression in CLL [31, 32]. In contrast, Döhner et al. [9] have documented that TP53 deletion is the strongest predictor for survival regardless of the presence of gene mutations analysed by single-stranded conformation polymorphism, and Grever et al. [33] described that TP53 mutations in the absence of $17 \mathrm{p}$ deletion do not have an independent negative impact on progression free survival. Thus, the best and optimal assay to establish the presence of TP53 abnormalities which is clinically significant is unknown.

We have analysed a series of 103 CLL patients from a single centre and they were selected on the basis that FISH and IHC were investigated at the same time point. There was not a bias for selection but our cohort included younger patients with a higher incidence of trisomy 12, p53 deletion, and unmutated IgVH than are seen in CLL. Our findings have shown that there is a good but not complete concordance between the presence of p53 protein overexpression and deletion of the TP53 gene. Although there have been several studies analysing the presence of p53 abnormalities in CLL, most of them focused in $17 \mathrm{p}$ deletion and TP53 mutations, and only a few investigated the presence of protein accumulation [34, 35]. The frequency of protein expression (15\%) in our study is similar to that reported by Cordone et al. [17] using immunocytochemistry in peripheral blood lymphocytes. It was more often (77\%) present in patients with advanced stages or progressive disease supporting previous studies [36, 37]. Flow cytometry (FACS) analysis has been proposed as an objective method for detecting p53 dysfunction [19]. However, unlike IHC, flow cytometry requires fresh or live cells and these are not always available. The advantage of bone marrow biopsies is that it can be done prospectively as well as retrospectively.

As expected, cases with concordant results and treated with fludarabine were resistant to the drug. The possibility 
Table 4 Cytogenetic

features, $\operatorname{IgVH}$ status and CD38 in cases with TP53 abnormalities
TP53 deletion + when present in $\geq 10 \%$ of cells

$N D$ Not determined

\begin{tabular}{|c|c|c|c|c|c|c|c|}
\hline Sample & IHC overexpression & TP53 deletion & +12 & $\operatorname{del}(11 q)$ & $\operatorname{del}(13 q)$ & CD38 & $\mathrm{IgVH}$ \\
\hline 1 & + & + & - & - & - & + & Mutated \\
\hline 2 & + & + & - & - & - & + & Unmutated \\
\hline 3 & + & + & + & - & + & + & Mutated \\
\hline 4 & + & + & - & - & - & + & Unmutated \\
\hline 5 & + & + & - & + & + & + & Unmutated \\
\hline 6 & + & + & - & - & - & + & Unmutated \\
\hline 7 & + & + & ND & ND & ND & - & ND \\
\hline 8 & + & + & ND & - & ND & + & ND \\
\hline 9 & + & + & + & - & - & + & Unmutated \\
\hline 10 & + & + & - & - & + & + & ND \\
\hline 11 & - & + & - & - & - & - & Unmutated \\
\hline 12 & - & + & + & - & + & + & Unmutated \\
\hline 13 & - & + & - & - & - & - & Unmutated \\
\hline 14 & - & + & - & - & + & + & Unmutated \\
\hline 15 & - & + & - & - & + & + & Unmutated \\
\hline 16 & - & + & - & - & - & & Unmutated \\
\hline 17 & - & + & - & - & - & + & Mutated \\
\hline 18 & - & + & + & - & + & + & Unmutated \\
\hline 19 & - & + & - & + & - & - & Unmutated \\
\hline 20 & - & + & - & + & + & + & Unmutated \\
\hline 21 & - & + & - & - & ND & + & ND \\
\hline 22 & + & - & - & - & + & - & Mutated \\
\hline 23 & + & - & + & - & - & + & Unmutated \\
\hline 24 & + & - & - & - & - & + & ND \\
\hline 25 & + & - & - & - & - & + & Unmutated \\
\hline 26 & + & - & - & - & + & ND & ND \\
\hline 27 & + & - & + & - & - & + & ND \\
\hline
\end{tabular}

that TP53 deletion could have been developed following fludarabine treatment by selecting a small resistant clone and/or these patients had been developed myelodysplasia could be entertained. However these scenarios are unlikely to be the responsible of the TP53 dysfunction as patients were primarily resistant to fludarabine and there was no evidence of dysplastic features in the bone marrow. Drug resistance was not significantly associated with $\mathrm{IgVH}$ mutational status, ATM deletion or trisomy 12 in this study.

Of interest is the finding of 17 cases in which the results between del17p and p53 protein expression were discordant,

Table 5 Response to fludarabine according to the TP53 status

\begin{tabular}{lllc}
\hline $\begin{array}{l}\text { Fludarabine treated } \\
\text { patients/no. of tested }\end{array}$ & $\begin{array}{l}\text { FISH } \\
(\geq 10 \%)\end{array}$ & IHC & $\begin{array}{l}\% \text { Refractory } \\
\text { cases }\end{array}$ \\
\hline $56 / 76$ & Negative & Negative & $14 \%(8 / 56)$ \\
$5 / 10$ & Positive & Positive & $100 \%(5 / 5)$ \\
$5 / 6$ & Negative & Positive & $60 \%(3 / 5)$ \\
$6 / 11$ & Positive & Negative & $33 \%(2 / 6)$ \\
\hline
\end{tabular}

and specially those six cases without deletion and with strong p53 expression. Considering the IHC positive and FISH negative group, two thirds of these cases treated with fludarabine were refractory.

Mutations of the TP53 gene were carried out by singlestrand conformation analysis and confirmed by direct sequencing [38] in 25 of the 27 patients that had TP53 abnormalities by one or both methods (data not shown). Mutations of the gene were identified in five of the 25 samples tested. Out of these five mutated cases, three had both TP53 deletion ( $>20 \%$ of cells) and marked overexpression of the protein, one case had p53 protein expression and no gene deletion and the remaining case had TP53 deletion ( $88 \%$ of cells) and no protein expression. Therefore there was evidence of TP53 dysfunction by the two or at least one method in all five mutated cases. Despite the lack of detectable mutations in the remaining cases, patients with deletion of the gene or protein expression were fludarabine resistant.

In agreement with recently published data [26, 39-41], most of the non-responders to fludarabine in our series responded to Alemtuzumab alone or in combination with 
prednisolone supporting the efficacy of these schedules in patients with $17 \mathrm{p}$ deletion.

In conclusion, our findings demonstrate that IHC is a simple and reliable method and a useful prognostic tool complementary to FISH analysis for the evaluation of TP53 abnormalities in CLL. Both methods can be carried out in routine practice to identify patients with a high chance to be resistant to fludarabine-containing regimens. Although the number of patients positive with both methods is low and studies on larger numbers of cases are needed, our findings suggest that IHC may allow identifying refractory patients without FISH abnormalities of the TP53 gene. The potential benefit of combining p53 protein expression by IHC and FISH for $17 \mathrm{p}$ deletion to detect poor risk CLL should be considered.

Acknowledgment This work has been partially supported by Fondo de Investigaciones Sanitarias. PM is in receipt of research grant from the ISCIII.

Conflict of interest The authors declare that they have no conflict of interest.

\section{References}

1. Chiorazzi N, Rai KR, Ferrarini M (2005) Chronic lymphocytic leukemia. N Engl J Med 352:804-815

2. Damle RN, Wasil T, Fais F, Ghiotto F, Valetto A, Allen SL, Buchbinder A, Budman D, Dittmar K, Kolitz J, Lichtman SM, Schulman P, Vinciguerra VP, Rai KR, Ferrarini M, Chiorazzi N (1999) Ig V gene mutation status and CD38 expression as novel prognostic indicators in chronic lymphocytic leukemia. Blood 94:1840-1847

3. Hamblin TJ, Davis Z, Gardiner A, Oscier DG, Stevenson FK (1999) Unmutated Ig $\mathrm{V}(\mathrm{H})$ genes are associated with a more aggressive form of chronic lymphocytic leukemia. Blood 94:1848-1854

4. Rassenti LZ, Jain S, Keating MJ, Wierda WG, Grever MR, Byrd JC, Kay NE, Brown JR, Gribben JG, Neuberg DS, He F, Greaves AW, Rai KR, Kipps TJ (2008) Relative value of ZAP-70, CD38, and immunoglobulin mutation status in predicting aggressive disease in chronic lymphocytic leukemia. Blood 112:1923-1930

5. Del Principe MI, Del Poeta G, Venditti A, Buccisano F, Maurillo L, Marini R, Cox MC, Panetta P, Suppo G, Degan M, Bruno A, Gattei V, Amadori S (2004) Clinical significance of soluble p53 protein in B-cell chronic lymphocytic leukemia. Haematologica 89:1468-1475

6. Crespo M, Bosch F, Villamor N, Bellosillo B, Colomer D, Rozman M, Marcé S, López-Guillermo A, Campo E, Montserrat E (2003) ZAP-70 expression as a surrogate for immunoglobulinvariable-region mutations in chronic lymphocytic leukemia. $\mathrm{N}$ Engl J Med 348:1764-1775

7. Kröber A, Seiler T, Benner A, Bullinger L, Brückle E, Lichter P, Döhner H, Stilgenbauer S (2002) V(H) mutation status, CD38 expression level, genomic aberrations, and survival in chronic lymphocytic leukemia. Blood 100:1410-1416

8. Wiestner A, Rosenwald A, Barry TS, Wright G, Davis RE, Henrickson SE, Zhao H, Ibbotson RE, Orchard JA, Davis Z, Stetler-Stevenson M, Raffeld M, Arthur DC, Marti GE, Wilson WH, Hamblin TJ, Oscier DG, Staudt LM (2003) ZAP-70 expression identifies a chronic lymphocytic leukemia subtype with unmutated immunoglobulin genes, inferior clinical outcome, and distinct gene expression profile. Blood 101:4944-4951

9. Döhner H, Fischer K, Bentz M, Hansen K, Benner A, Cabot G, Diehl D, Schlenk R, Coy J, Stilgenbauer S et al (1995) p53 gene deletion predicts for poor survival and non-response to therapy with purine analogs in chronic B-cell leukemias. Blood 85:15801589

10. Montillo M, Hamblin T, Hallek M, Montserrat E, Morra E (2005) Chronic lymphocytic leukemia: novel prognostic factors and their relevance for risk-adapted therapeutic strategies. Haematologica 90:391-399

11. Lin KI, Tam CS, Keating MJ, Wierda WG, O’Brien S, Lerner S, Coombes KR, Schlette E, Ferrajoli A, Barron LL, Kipps TJ, Rassenti L, Faderl S, Kantarjian H, Abruzzo LV (2009) Relevance of the immunoglobulin $\mathrm{VH}$ somatic mutation status in patients with chronic lymphocytic leukemia treated with fludarabine, cyclophosphamide, and rituximab (FCR) or related chemoimmunotherapy regimens. Blood 113:3168-3171

12. Cheung K-JJ, Horsman DE, Gascoyne RD (2009) The significance of TP53 in lymphoid malignancies: mutation prevalence, regulation, prognostic impact and potencial as a therapeutic target. $\mathrm{Br} \mathrm{J}$ Haematol 146:257-269

13. Zenz T, Benner A, Döhner H, Stilgenbauer S (2008) Chronic lymphocytic leukemia and treatment resistance in cancer: the role of the p53 pathway. Cell Cycle 7:3810-3814

14. Martin AC, Facchiano AM, Cuff AL, Hernandez-Boussard T, Olivier M, Hainaut P, Thornton JM (2002) Integrating mutation data and structural analysis of the TP53 tumor-suppressor protein. Hum Mutat 19:149-164

15. Chang H, Yeung J, Qi C, Xu W (2007) Aberrant nuclear p53 protein expression detected by immunohistochemistry is associated with hemizygous $\mathrm{P} 53$ deletion and poor survival for multiple myeloma. $\mathrm{Br}$ J Haematol 138:324-329

16. Rassidakis GZ, Thomaides A, Wang S, Jiang Y, Fourtouna A, Lai $\mathrm{R}$, Medeiros LJ (2005) p53 gene mutations are uncommon but p53 is commonly expressed in anaplastic large-cell lymphoma. Leukemia 19:1663-1669

17. Cordone I, Masi S, Mauro FR, Soddu S, Morsilli O, Valentini T, Vegna ML, Guglielmi C, Mancini F, Giuliacci S, Sacchi A, Mandelli F, Foa R (1998) p53 expression in B-cell chronic lymphocytic leukemia: a marker of disease progression and poor prognosis. Blood 91:4342-4349

18. Aguilar-Santelises M, Rottenberg ME, Lewin N, Mellstedt H, Jondal M (1996) Bcl-2, Bax and p53 expression in B-CLL in relation to in vitro survival and clinical progression. Int $\mathrm{J}$ Cancer 69:114-119

19. Thornton PD, Gruszka-Westwood AM, Hamoudi RA, Atkinson S, Kaczmarek P, Morilla RM, Hilditch BL, A'Hern R, Matutes E, Catovsky D (2004) Characterisation of TP53 abnormalities in chronic lymphocytic leukaemia. Hematol J 5:47-54

20. Swerdlow SH, Campo E, Harris NL, Jaffe ES, Pileri SA, Stein H, Thiele J, Vardiman JW (eds) (2008) WHO classification of tumours of haematopoietic and lymphoid tissues. International Agency for Research on Cancer, Lyon

21. Matutes E, Owusu-Ankomah K, Morilla R, Garcia Marco J, Houlihan A, Que TH, Catovsky D (1994) The immunological profile of B-cell disorders and proposal of a scoring system for the diagnosis of CLL. Leukemia 8:1640-1645

22. Morilla A, Gonzalez de Castro D, Del Giudice I, Osuji N, Else M, Morilla R, Brito Babapulle V, Rudenko H, Matutes E, Dearden C, Catovsky D, Morgan GJ (2008) Combinations of ZAP-70, CD38 and IGHV mutational status as predictors of time to first treatment in CLL. Leuk Lymphoma 49:2108-2115

23. Oscier D, Wade R, Davis Z, Morilla A, Best G, Richards S, Else M, Matutes E, Catovsky D (2010) Prognostic factors identify 3 
risk groups in the LRF CLL4 trial, independent of treatment allocation Haematologica 95:1705-1712

24. Oda Y, Sakamoto A, Satio T, Kawauchi S, Iwamoto Y, Tsuneyoshi M (2000) Molecular abnormalities of p53, MDM2, and H-ras in synovial sarcoma. Mod Pathol 13:994-1004

25. Hallek M, Cheson BD, Catovsky D, Caligaris-Cappio F, Dighiero G, Döhner H, Hillmen P, Keating MJ, Montserrat E, Rai KR, Kipps TJ (2008) International Workshop on Chronic Lymphocytic Leukemia. Guidelines for the diagnosis and treatment of chronic lymphocytic leukemia: a report from the International Workshop on Chronic Lymphocytic Leukemia updating the National Cancer Institute-Working Group 1996 guidelines. Blood 111:5446-5456

26. Catovsky D, Richards S, Matutes E, Oscier D, Dyer MJ, Bezares RF, Pettitt AR, Hamblin T, Milligan DW, Child JA, Hamilton MS, Dearden CE, Smith AG, Bosanquet AG, Davis Z, Brito-Babapulle V, Else M, Wade R, Hillmen P (2007) UK National Cancer Research Institute (NCRI) Haematological Oncology Clinical Studies Group; NCRI Chronic Lymphocytic Leukaemia Working Group. Assessment of fludarabine plus cyclophosphamide for patients with chronic lymphocytic leukaemia (the LRF CLL4 Trial): a randomised controlled trial. Lancet 370:230-239

27. Eichhorst BF, Busch R, Hopfinger G, Pasold R, Hensel M, Steinbrecher C, Siehl S, Jäger U, Bergmann M, Stilgenbauer S, Schweighofer C, Wendtner CM, Döhner H, Brittinger G, Emmerich B, Hallek M (2006) German CLL Study Group. Fludarabine plus cyclophosphamide versus fludarabine alone in first-line therapy of younger patients with chronic lymphocytic leukemia. Blood 107:885-891

28. Flinn IW, Neuberg DS, Grever MR, Dewald GW, Bennett JM, Paietta EM, Hussein MA, Appelbaum FR, Larson RA, Moore DF Jr, Tallman MS (2007) Phase III trial of fludarabine plus cyclophosphamide compared with fludarabine for patients with previously untreated chronic lymphocytic leukemia: US Intergroup Trial E2997. J Clin Oncol 25:793-798

29. Cheson BD, Bennett JM, Grever M, Kay N, Keating MJ, O'Brien S, Rai KR (1996) National Cancer Institute-sponsored Working Group guidelines for chronic lymphocytic leukemia: revised guidelines for diagnosis and treatment. Blood 87:49904997

30. Leporrier M, Chevret S, Cazin B, Boudjerra N, Feugier P, Desablens B, Rapp MJ, Jaubert J, Autrand C, Divine M, Dreyfus B, Maloum K, Travade P, Dighiero G, Binet JL, Chastang C (2001) French Cooperative Group on Chronic Lymphocytic Leukemia. Randomized comparison of fludarabine, CAP, and CHOP in 938 previously untreated stage $\mathrm{B}$ and $\mathrm{C}$ chronic lymphocytic leukemia patients. Blood 98:2319-2125

31. Giles FJ, Bekele BN, O'Brien S, Cortes JE, Verstovsek S, Balerdi M, Yared M, Zhou X, Kantarjian HM, Keating MJ, Thall P, Albitar M (2003) A prognostic model for survival in chronic lymphocytic leukaemia based on p53 expression. Br J Haematol 121:578-585

32. Dicker F, Herholz H, Schnittger S, Nakao A, Patten N, Wu L, Kern W, Haferlach T, Haferlach C (2009) The detection of TP53 mutations in chronic lymphocytic leukemia independently predicts rapid disease progression and is highly correlated with a complex aberrant karyotype. Leukemia 23:117-124

33. Grever MR, Lucas DM, Dewald GW, Neuberg DS, Reed JC, Kitada S, Flinn IW, Tallman MS, Appelbaum FR, Larson RA, Paietta E, Jelinek DF, Gribben JG, Byrd JC (2007) Comprehensive assessment of genetic and molecular features predicting outcome in patients with chronic lymphocytic leukemia: results from the US Intergroup Phase III Trial E2997. J Clin Oncol 25:799-804

34. Chang H, Jiang AM, Qi CX (2010) Aberrant nuclear p53 expression predicts hemizygous 17p (TP53) deletion in chronic lymphocytic leukaemia. Am J Clin Pathol 133:70-74

35. Schlette EJ, Admirand J, Wierda W, Abruzzo L, Lin KI, O’Brien S, Lerner S, Keating MJ, Tam C (2009) p53 expression by immunohistochemistry is an important determinant of survival in patients with chronic lymphocytic leukaemia receiving frontline chemoimmunotherapy. Leuk Lymphoma 50:1597-1605

36. Gaidano G, Newcomb EW, Gong JZ, Tassi V, Neri A, Cortelezzi A, Calori R, Baldini L, Dalla-Favera R (1994) Analysis of alterations of oncogenes and tumor suppressor genes in chronic lymphocytic leukemia. Am J Pathol 144:1312-1319

37. Fenaux P, Preudhomme C, Laï JL et al (1992) Mutations of the p53 gene in B-cell chronic lymphocytic leukemia: a report on 39 cases with cytogenetic analysis. Leukemia 6:246-250

38. Gonzalez D, Martinez P, Rudenko H, Brito V, Gonzalez M, Hernandez JM, Matutes E, Dearden C, Catovsky D, Morgan G (2007) Multiplex fluorescent single-strand conformation analysis (SSCA) as a sensitive method for detecting TP53 mutations in CLL. Leuk Lymphoma 48(supp11):S139

39. Stilgenbauer S, Dohner H (2002) Campath-1H-induced complete remission of chronic lymphocytic leukemia despite p53 gene mutation and resistance to chemotherapy. N Engl J Med 347:452-453

40. Elter T, Borchmann P, Schulz H, Reiser M, Trelle S, Schnell R, Jensen M, Staib P, Schinköthe T, Stützer H, Rech J, Gramatzki M, Aulitzky W, Hasan I, Josting A, Hallek M, Engert A (2005) Fludarabine in combination with alemtuzumab is effective and feasible in patients with relapsed or refractory B-cell chronic lymphocytic leukemia: results of a phase II trial. J Clin Oncol 23:7024-7031

41. Faderl S, Thomas DA, O'Brien S, Garcia-Manero G, Kantarjian HM, Giles FJ, Koller C, Ferrajoli A, Verstovsek S, Pro B, Andreeff M, Beran M, Cortes J, Wierda W, Tran N, Keating MJ (2003) Experience with alemtuzumab plus rituximab in patients with relapsed and refractory lymphoid malignancies. Blood 101:3413-3415 